\section{East African Community (EAC)}

The East African Community (EAC) was formally established on 30 Nov. 1999 with the signing in Arusha, Tanzania of the Treaty for the Establishment of the East African Community. The Treaty envisages the establishment of a Customs Union, as the entry point of the Community, a Common Market, subsequently a Monetary Union and ultimately a Political Federation of the East African States. In Nov. 2003 the EAC partner states signed a Protocol on the Establishment of the East African Customs Union, which came into force on 1 Jan. 2005.

Members. Kenya, Tanzania, Uganda.

Headquarters: PO Box 1096, Arusha, Tanzania.

Website: http://www.eac.int

Secretary General: Juma Mwapachu (Tanzania).

\section{East African Development Bank (EADB)}

Established originally under the Treaty for East African Cooperation in 1967 with Kenya, Tanzania and Uganda as signatories, a new Charter for the Bank (with the same signatories) came into force in 1980. Under the original Treaty the Bank was confined to the provision of financial and technical assistance for the promotion of industrial development in member states but with the new Charter its remit was broadened to include involvement in agriculture, forestry, tourism, transport and the development of infrastructure, with preference for projects which promote regional co-operation.

Official language: English.

Headquarters: 4 Nile Avenue, Kampala, Uganda.

Website: http://www.eadb.org

Chairman of the Board: Christopher Kassami (Uganda).

\section{Economic Community of Central African States (CEEAC)}

The Economic Community of Central African States (Communauté Economique des Etats de l'Afrique Centrale) was established in 1983 to promote regional economic co-operation and to establish a Central African Common Market. There are plans for a free trade zone to be established.

Members. Angola, Burundi, Cameroon, Central African Republic, Chad, Democratic Republic of the Congo, Republic of the Congo, Equatorial Guinea, Gabon, Rwanda, São Tomé e Príncipe.

Headquarters: BP 2112, Libreville, Gabon.

President: Denis Sassou-Nguesso (Republic of the Congo). Secretary-General: Louis Sylvain-Goma (Republic of the Congo).

\section{Economic Community of West African States (ECOWAS)}

Founded in 1975 as a regional common market, and now aiming to operate a single currency zone in 2009, ECOWAS later also became a political forum involved in the promotion of a democratic environment and the pursuit of fundamental human rights. In July 1993 it revised its treaty to assume responsibility for the regulation of regional armed conflicts, acknowledging the inextricable link between development and peace and security. Thus it now has a new role in conflict management and prevention through its Mediation and Security Council, which monitors the moratorium on the export, import and manufacture of light weapons and ammunition. However, it still retains a military arm, ECOMOG. It is also involved in the war against drug abuse and illicit drug trafficking.

Members. Benin, Burkina Faso, Cape Verde, Côte d'Ivoire, The Gambia, Ghana, Guinea, Guinea-Bissau, Liberia, Mali, Niger, Nigeria, Senegal, Sierra Leone, Togo.

Organization. It meets at yearly summits which rotate in the different capitals of member states. The institution is governed by the Council of Ministers, and has a secretariat in Abuja which is run by an Executive Secretary.

Official languages: English, French, Portuguese.

Headquarters: 60 Yakubu Gowon Crescent, Asokoro, Abuja, Nigeria.

Website: http://www.ecowas.int

e-mail:info@ecowasmail.net

Executive Secretary: Dr Mohamed Ibn Chambas (Ghana).

\section{Intergovernmental Authority on Development}

The Intergovernmental Authority on Development was created on 21 March 1996 and has its origins in the Intergovernmental Authority on Drought and Development, which had been established in 1986. It has three priority areas of co-operation: conflict prevention, management and humanitarian affairs; infrastructure development; food security and environment protection.

Members. Djibouti, Eritrea, Ethiopia, Kenya, Somalia, Sudan, Uganda.

Headquarters: PO Box 2653, Djibouti, Republic of Djibouti. Website: http://www.igad.org

Executive Secretary: Dr Attalla Hamad Bashir (Sudan).

\section{Lake Chad Basin Commission}

Established by a Convention and Statute signed on 22 May 1964 by Cameroon, Chad, Niger and Nigeria, and later by the Central African Republic, to regulate and control utilization of the water and other natural resources in the Basin (Sudan has also been admitted as an observer); to initiate, promote and co-ordinate natural resources development projects and research within the Basin area; and to examine complaints and promote settlement of disputes, with a view to promoting regional co-operation.

In Dec. 1977, at Enugu in Nigeria, the 3rd summit of heads of state of the commission signed the protocol for the Harmonization of the Regulations Relating to Fauna and Flora in member countries, and adopted plans for the multi-donor approach towards major integrated development for the conventional basin. An international campaign to save Lake Chad following a report on the environmental degradation of the conventional basin was 